\title{
HUBUNGAN ANTARA KONTROL DIRI DENGAN PERILAKU SEKSUAL REMAJA PADA SISWA SMK ISTIQOMAH MUHAMMADIYAH 4 SAMARINDA
}

\author{
RELATIONSHIP BETWEEN SELF CONTROL BY SEXUAL BEHAVIOR IN ADOLESCENT \\ STUDENTS SMK ISTIQOMAH MUHAMMADIYAH 4 SAMARINDA
}

\section{RIZALI NOOR}

Fakultas Psikologi, Universitas 17 Agustus 1945 Samarinda

Email : rizalinoor1921@gmail.com

\begin{abstract}
Abstrak: Penelitian ini bertujuan untuk mengetahui apakah terdapat hubungan yang signifikan antara kontrol diri dengan perilaku seksual Remaja Pada Siswa SMK Istiqomah Muhammadiyah 4 Samarinda. Populasi dalam penelitian ini adalah siswa kelas XI dan XII yang berjumlah 958 orang. Pengambilan sampel pada penelitian ini menggunakan teknik sampling. Instrument dalam penelitian ini adalah skala kontrol diri dan skala perilaku seksual yang diadopsi dan disusun peneliti sendiri.Teknik analisis data yang digunakan yang digunakan adalah analisis regresi sederhana dengan bantuan program SPSS 23 for windows. Hasil penelitian menunjukkan bahwa : 1). Pada umumnya siswa memiliki kontrol yang sedang. 2). Pada umumnya siswa memilki tingkat perilaku seksual yang sedang. 3). Ada hubungan negatif antara kontrol diri terhadap perilaku seksual $(\mathrm{p}=0,000, \mathrm{p}<0,05)$, dengan koefisien korelasi $0,268(\mathrm{r}=-0,518)$ dan sumbangan kontrol diri terhadap perilaku seksual sebesar 35,90. Hal ini menunjukkan bahwa semakin tinggi kontrol diri maka semakin rendah perilaku seksual.
\end{abstract}

Kata Kunci : Kontrol Diri, Perilaku Seksual

Abstract: This study aims to determine the relationship between self control against. The population in the study were students in grade XI dan XII SMK Istiqomah Muhammadiyah 4 Samarinda amounting to 958 people. Samples drawn by using random sampling. Instrument in this study is the scala self control and sexual behavior scala adopted and prepared researchers themselves. The research data ware analyzed using sample regression with SPPS 13,00 for windows. The results of this study indicate that : 1) In general, students have the self control that was. 2) In general, students have high levels of adolescent sexual behavior being. 3) The is a negative relationship between self control ( $p=0.000, p<0.05)$, with a colrelation coefficient of 0,268 ( $r=-0,518)$, self control and effective contribution adolescent sexual behavior for 35,90. This suggests that the higher the lower the self control adolescent sexual behavior.

Keywords : self control, adolescent sexual behavior. 


\section{PENDAHULUAN}

Fase remaja merupakan suatu fase yang rentan mengingat banyak terjadi perubahan baik dalam aspek fisik, psikologis maupun sosial. Fase ini remaja penuh dengan keinginan akan kebebasan diri yang dipenuhi dengan semangat, cinta, harapan, aktivitas, imajinasi, dan rasa ingin tahu. Umumnya remaja pada fase ini berstatus sebagai Siswa Sekolah Menengah Atas (SMA) atau Kejuruan (SMK) yang berada pada usia 15-18 tahun.

Kematangan dan perkembangan seorang remaja sering kali terpengaruhi oleh banyaknya masalah yang dihadapi baik secara internal maupun eksternal. Masalah-masalah tersebut mulai dari keinginan untuk pacaran, sakit hati, kurang percaya diri, merasa tidak puas dengan apa yang ada, ego yang tinggi, pergaulan bebas dan sebagainya. Terkait dengan keinginan untuk mulai berpacaran, tertarik dengan lawan jenis atau pergaulan bebas, remaja perlu mendapatkan tambahan wawasan yang lebih detail tentang hubungan antara laki-laki dengan perempuan dan mengenai bagaimana pergaulan atau pacaran yang sehat. Kebanyakan siswa tidak berani menolak kalau pacarnya ingin berbuat seks, sehingga mereka melakukan hubungan seks. Semua ini dapat terjadi karena kepribadian dan tingkat penalaran moral siswa yang kurang baik. Keberhasilan perkembangan penalaran moral remaja di masyarakat ikut menentukan keberhasilan remaja dalam menentukan pola pergaulannya di masyarakat.

Hal inilah yang paling mendominasi dan menjadi hot topik di kalangan para remaja kita. Salah satu masalah yang sangat menarik untuk diteliti peneliti adalah masalah perilaku seksual remaja khususnya remaja siswa Siswa Sekolah Menengah Atas (SMA) atau Kejuruan (SMK) berada pada usia 15-18 tahun, betapa tidak pada tahun 2014 usia remaja yang berumur 10-24 tahun sekitar 64 juta atau $28,6 \%$ dari jumlah penduduk Indonesia sebanyak 222 juta. Ada 21 juta remaja Indonesia sudah berhubungan seks. $62,7 \%$ pelajar pernah melakukan hubungan seksual. 21,2 \% pelajar pernah melakukan aborsi. $\quad 93,7 \%$ pernah berciuman, melakukan genital stimulation, dan oral sex. $97 \%$ pernah menonton film porno. (Kuncoro, 2015)

Berbagai penyebab eksternal ditenggarai mengancam kehidupan remaja, salah satunya adalah penyebaran konten pornografi yang semakin masif. Menurut hasil seminar sehari bersama dr. Boyke Dian Nugraha, Sp. OG, MARS pada peringatan hari AIDS sedunia di Surabaya pada tanggal 24 Desember 2005, salah satunya mengatakan bahwa kenikmatan tentang cinta dan hubungan seks yang ditawarkan oleh berbagai informasi, baik berupa majalah, tayangan telenovela, film \& internet mengakibatkan fantasi seksual pada diri remaja berkembang dengan cepat. dr. Boyke Dian Nugraha, Sp. OG, MARS juga mengatakan, "Semakin banyak seseorang melakukan fantasi seksual maka makin cenderung untuk melakukan aktifitas seksual".

Penelitian lain menunjukkan bahwa remaja laki-laki yang terpengaruh terhadap buku-buku porno sebesar 59,3\% dan film-film porno sebesar $48,8 \%$. Sementara pada remaja putri yang terpengaruh pada buku porno sebesar $28,4 \%$ dan pada film-film porno sebesar $15,9 \%$ (dalam Yulianto, 2010).

Penyebab internal yang menyebabkan remaja melakukan perilaku seksual yang tidak sehat adalah sikap permisif, kurangnya kontrol diri, tidak bisa mengambil keputusan mengenai kehidupan seksual yang sehat atau tidak bisa bersikap asertif terhadap ajakan teman atau pacar (Kartika dan Farida, 2008).

Berdasarkan uraian-uraian tersebut memperlihatkan bahwa kontrol diri memiliki keterkaitan dengan perilaku seksual pada remaja. Keterkaitan antara kontrol diri dengan perilaku seksual pada remaja memperlihatkan bahwa kemampuan mengendalikan diri remaja berperan penting dalam menekan perilaku seksual remaja baik yang berbentuk perilaku seksual remaja masturbasi, pacaran dan senggama. Dengan adanya kontrol diri yang kuat, remaja dapat menekan stumulus-stimulus negatif baik dari dalam diri maupun dari luar diri yang dapat mempengaruhi perilaku seksual remaja tersebut.

Peranan kontrol diri remaja merupakan salah satu unsur yang sangat penting dari tugastugas perkembangan yaitu memperkuat selfcontrol (kemampuan mengendalikan diri) atas dasar skala nilai, prinsip-prinsip atau falsafah hidup. Lazarus (dalam Thalib, 2010) menjelaskan bahwa kontrol diri menggambarkan keputusan individu melalui pertimbangan kognitif untuk menyatukan perilaku yang telah disusun guna meningkatkan hasil dan tujuan tertentu sebagaimana yang diinginkan. Remaja yang memiliki kontrol diri yang baik akan mempertimbangkan apa yang sesuai dengan dirinya tetapi juga mementingkan perasaan orangtua dan teman sebayanya (komfirmitas). 
Hal ini pula yang harus dihadapi para siswa SMK Istiqomah Muhamadiyah 4 Samarinda dalam menghadapi persoalan perilaku seksual yang ada pada setiap diri mereka sebagai makhluk sosial ditengah derasnya arus globalisasi dan perkembangan teknologi dalam menuntaskan tugas-tugas perkembangan yang diemban mereka.

Berdasarkan fenomena diatas peneliti tertarik untuk mengadakan penelitian yang berjudul "Hubungan Antara Kontrol Diri Dengan Perilaku Seksual Remaja Pada Siswa SMK Istiqomah Muhammadiyah 4 Samarinda ".

\section{METODE PENELITIAN}

\section{Tipe Penelitian}

Tipe penelitian ini yaitu kuantitatif korelasional, penelitian ini bersifat menjelaskan hubungan dua variabel yang diteliti yaitu hubungan antara perilaku seksual remaja dengan kontrol diri.

Dalam penelitian ini, peneliti juga mengunakan penelitian deskriptif yaitu penelitian yang berusaha untuk menjelaskan atau menerangkan suatu peristiwa berdasarkan data.

Penelitian deskriptif digunakan untuk mendeskripsikan kontrol diri dengan perilaku seksual remaja. Penelitian korelasional digunakan untuk mengetahui ada tidaknya hubungan antara kontrol diri dengan perilaku seksual remaja.

\section{Subyek Penelitian}

\section{a. Populasi}

Populasi (Sugiyono, 2011) adalah wilayah generalisasi yang terdiri atas obyek atau subjek yang mempunyai kualitas dan karakteristik tertentu yang ditetapkan oleh peneliti untuk dipelajari dan kemudian ditarik kesimpulannya. Populasi yang akan digunakan dalam penelitian ini adalah seluruh siswa di SMK Istiqomah Muhammadiyah 4 Samarinda berjumlah 958 orang baik berjenis kelamin laki-laki atau wanita yang berusia antara 15 hingga 18 tahun.

\section{b. Sampel}

Sampel adalah bagian dari jumlah dan karakteristik yang dimiliki oleh populasi tersebut (Sugiyono, 2011). Penentuan sampel pada penelitian ini menggunakan teknik random sampling, karena subyek yang dipilih adalah siswa kelas XI dan XII di SMK Istiqomah Muhammadiyah 4 Samarinda berjumlah 100 orang yang berusia antara 15 hingga 18 tahun (Sugiyono, 2011) berjenis kelamin lakilaki dikarenakan sekolah kejuruan teknik.

\section{HASIL DAN PEMBAHASAN}

\section{Gambaran Deskriptif Kontrol Diri terhadap Perilaku Seksual.}

Hasil analisis data menunjukkan bahwa hipotisis yang menyatakan ada hubungan negatif antara perilaku seksual dan kontrol diri diterima (terbukti). Hubungan antara kedua variable ini ditunjukkan dengan nilai $r$ sebesar 0,518. Hal ini berarti bahwa semakin rendah perilaku seksual siswa, makin tinggi kontrol diri. Sebaliknya makin tinggi kontrol diri siswa, makin rendah perilaku seksual siswa.

Menurut Hurlock (2004), manifestasi dorongan seksual dalam perilaku seksual dipengaruhi oleh faktor internal dan faktor eksternal. Faktor internal yaitu stimulus yang berasal dari dalam individu berupa bekerjanya hormon-hormon alat reproduksi. Hormon tersebut dapat menimbulkan dorongan seksual yang menuntut pemuasan. Sedangkan faktor eksternal. Misalnya saja, perkembangan biologis menyebabkan timbulnya perubahan-perubahan tertentu, baik yang bersifat fisiologis yang cepat dan disertai percepatan perkembangan mental yang cepat, terutama pada masa remaja awal. Semua perkembangan itu menimbulkan perlunya penyesuaian mental dan perlunya membentuk sikap, nilai, dan minat baru. Minat baru yang dominan muncul pada masa remaja adalah minatnya terhadap seks. Pada masa remaja ini mereka berusaha melepaskan ikatan-ikatan afektif lama dengan orang tua. Remaja lalu berusaha membangun relasirelasi afektif yang baru dan yang lebih matang dengan lawan jenis dan dalam memainkan peran yang lebih tepat dengan seksnya. Dorongan untuk melakukan ini datang dari tekanan-tekanan sosial akan tetapi terutama dari minat remaja pada seks dan keingintahuannya tentang seks. Karena 
meningkatnya minat pada seks, maka remaja berusaha mencari lebih banyak informasi mengenai seks. Tidak jarang, karena dorongan fisiologis ini juga, remaja mengadakan percobaan dengan jalan masturbasi, bercumbu, atau bersenggama.

Penelitian oleh Kanin, Davidson dan Sheck (dalam Papalia, Old \& Feldman, 2008) menyebutkan bahwa orang yang sedang jatuh cinta mengalami reaksi yang bersifat psikologis dan diikuti oleh beberapa reaksi fisiologis. Rasa senang dan nyaman yang dirasakan oleh pasangan yang sedang menjalin hubungan romantis, pada umumnya diwujudkan dalam bentuk-bentuk perilaku berupa sentuhan yang dapat menyenangkan pasangannya. Berdasarkan hal tersebut maka kemungkinan perilaku-perilaku yang bersifat seksual dapat terjadi.

Hurlock (2004) mengatakan kontrol diri berkaitan dengan bagaimana individu mengendalikan emosi serta dorongandorongan dalam dirinya. Kontrol diri diperlukan guna membantu individu dalam mengatasi kemampuannya yang terbatas dan membantu mengatasi berbagai hal merugikan yang dimungkinkan berasal dari luar.

Berani menolak perilaku seksual kalau pacarnya ingin melakukan hubungan seks secara bebas, karena kepribadian dan tingkat penalaran moral siswa yang baik. Perlu adanya pembinaan nilai-nilai moral sejak dini tanpa menggunakan larangan atau hukuman, namun dengan jalan anak selalu diajak untuk berfikir, yang selalu menerangkan mengapa suatu perbuatan dilarang atau diperintahkan, apa maksudnya dan apa motivasinya, sehingga mereka akan menjadi orang yang selalu terbuka terhadap sesuatu yang baru; termasuk pergaulan seks bebas dan yang akan bertindak berdasarkan tanggung jawab yang nyata.

Kartono (2005) mengatakan bahwa perbuatan seksual pada anak remaja pada umumya disebabkan oleh disharmoni dalam kehidupan psikisnya, yang ditandai dengan bertumpuknya konflik-konflik batin, kurangnya rem-rem terhadap nafsu-nafsu hewani, kurang berfungsinya kemauan dan hati nurani serta kurang tajamnya intelek untuk mengendalikan nafsu seksual yang bergelora.

Dengan adanya kontrol diri, individu terhindar dari perilaku menyimpang, Tangney (2004) menyebutkan rendahnya kontrol diri berkorelasi dengan perilaku melanggar. Gottfredson dan Hirschi (dalam Delisi \& Vaughn, 2007) salah satu prediktor yang konsisten terjadinya kejahatan ialah rendahnya kontrol diri.

Orang tua dan guru kurang tanggap dan menganggap masalah seksualitas pada remaja merupakan hal yang tabu dan memandang pendidikan seks sebagai pelajaran hubungan seksual antara laki-laki dan perempuan.

\section{Hubungan antara Kontrol Diri terhadap Perilaku Seksual Siswa SMK Istiqomah Muhammadiyah 4 Samarinda}

Kontrol diri mampu menjelaskan perilaku seksual pada remaja sebesar 51,8\%, sedangkan sisanya yakni sebesar $48,2 \%$ dijelaskan oleh variabel lain yang tidak disertakan dalam penelitian ini di antaranya pendidikan tentang seksual.

Adanya hubungan antara kontrol diri dengan perilaku seksual juga ditunjukkan oleh hasil uji linearitas yang dilakukan terhadap kedua variabel tersebut. Hal itu ditunjukkan dengan hasil uji linearitas dengan nilai $F$ sebesar 41,937 dengan nilai $p$ sebesar $0,017$ ( $\mathrm{p}<0,05)$.

Hasil tersebut memperlihatkan bahwa hubungan antara kontrol diri dengan perilaku seksual pada remaja bersifat linear, dalam arti bahwa kedua variabel saling berhubungan satu sama lain.

Adanya hubungan yang negatif antara kontrol diri dengan perilaku seksual pada remaja ini memperlihatkan besarnya peranan penguasaan diri pada remaja untuk mengendalikan diri dari pengaruh hal-hal yang bersifat negatif khususnya berhubungan dengan perilaku seksual. Keterkaitan antara kontrol diri dengan perilaku seksual pada remaja memperlihatkan bahwa kemampuan mengendalikan diri remaja berperan penting dalam menekan perilaku seksualnya. Perilaku seksual pada remaja dapat ditekan apabila terdapat kontrol diri yang kuat. Remaja yang memiliki kontrol diri kuat mampu menahan atau mengendalikan dorongan-dorongan seksual yang timbul dari dalam dirinya. Rasa ingin tahu remaja yang tidak ditunjang dengan pengetahuan dan pemahaman yang memadai tentang seksual dapat memperlemah kontrol dirinya. Hal ini disebabkan remaja hanya ingin memuaskan rasa ingin tahunya 
tanpa mempertimbangkan 0atau memperhitungkan segala konsekuensi atas perilakunya. Oleh sebab itu, informasi yang tepat mengenai seksual penting bagi kalangan remaja agar dapat meningkatkan kontrol dirinya terhadap dorongan-dorongan yang mengarah pada timbulnya perilaku seksual. Dengan demikian, semakin kuat kontrol diri yang dimiliki remaja, maka perilaku seksualnya semakin rendah. Sebaliknya, apabila kontrol diri yang dimiliki remaja semakin lemah, maka perilaku seksualnya semakin tinggi.

Berdasarkan segi waktu yang dihabiskan oleh remaja di sekolah, Pendidikan di SMK Istiqomah Muhammadiyah 4 Samarinda. yang lebih menekankan pendidikan agama pada siswa, belum cukup untuk meniadakan kemungkinan perilaku seksual. Hal ini dikarenakan waktu siswa untuk berada dalam pengawasan sekolah dimana guru-guru memberikan pendidikan agama dan penerapan tata tertib sekolah harus dipatuhi oleh siswa hanya sebatas jam-jam wajib belajar siswa. Sedangkan waktu siswa diluar jam sekolah membuat siswa berperilaku tanpa pengawasan langsung dari sekolah, seperti waktu dirumah yang lebih dipengaruhi faktor pola asuh orang tua, dan waktu bermain lebih dipengaruhi lingkungan sosialnya. Hal inilah yang dapat menyebabkan perilaku seksual tetap terjadi pada remaja sekalipun remaja tersebut memiliki latar belakang sekolah dengan pendidikan agama yang lebih banyak dibandingkan sekolah lain.

\section{KESIMPULAN}

Penelitian ini meneliti tentang perilaku seksual dan kontrol diri pada siswa SMK Istiqomah Muhammadiyah 4 Samarinda dan dilakukan dilakukan di SMK Istiqomah Muhammadiyah 4 Samarinda. Penelitian ini menggunakan metode kuantitatif korelasional untuk mengetahui signifikansi hubungan antara perilaku seksual dan kontrol diri. Subyek penelitian ini adalah telah dikenakan kepada 100 siswa SMK Istiqomah Muhammadiyah 4 Samarinda kelas XI dan XII. Pengambilan sampel diambil secara purposive sampling sehingga didapatkan 100 siswa tersebut sebagai sampel pada penelitian ini. Alat ukur yang digunakan pada penelitian ini adalah skala perilaku seksual yang terdiri 28 aitem dan kontrol diri yang terdiri dari 24 aitem. Teknik analisis data menggunakan teknik analisa regresi sederhana.

Hasil uji hipotesis dengan menggunakan teknik analisis regresi untuk perilaku seksual dan kontrol diri didapatkan nilai beta $=0,518, \mathrm{t}=0,59992$, dan $\mathrm{p}=$ 0.000 . Dengan nilai $\mathrm{p}=0.000<0.05$ dapat disimpulkan bahwa terdapat hubungan yang signifikan antara perilaku seksual dengan kontrol diri pada SMK Istiqomah Muhammadiyah 4 Samarinda kelas XI dan XII.

Kontrol diri mampu menjelaskan perilaku seksual pada remaja sebesar 51,8\%, sedangkan sisanya yakni sebesar 48,2\% dijelaskan oleh variabel lain yang tidak dikontrol dalam penelitian ini di antaranya pendidikan seksual.

\section{DAFTAR PUSTAKA}

Aritkunto, Suharsimi. 2002. Prosedur Penelitian Suatu Pendekatan Praktek. Jakarta: rieneka.

Azwar, S. 1999. Penyusunan Skala Psikologi. Yogyakarta: Pustaka Pelajar. 2001. Metode Penelitian.

Yogyakarta: Pustaka Pelajar.

2011. Sikap Manusia, Teori dan Pengukurannya. Yogyakarta: Pustaka Pelajar.

Yogyakarta: Pustaka Pelajar.

Ating Somantri, $(2012,24,12)$. Contoh-Skala Likert-Penelitian. Duniapelajar (on-line). Diakses pada tanggal 11 April 2015 dari http:

//www.duniapelajar.com/2012/12/24/conto h-skala-likert-penelitian).

Bertens K, 2010, Memperkenalkan Psikoanalisa, Lima Ceramah, Jakarta, PT. Gramedia

Chaplin, J.P. 2005.Kamus Lengkap Psikologi. Jakarta: PT Raja Grafindo Persada. 
Hurlock, E.B. 2004. Psikologi Perkembangan: Suatu Pendekatan Sepanjang Rentang Kehidupan. Jakarta: Erlangga.

Iga Serpianing Aroma \& Dewi Retno Suminar (2012). Hubungan Antara Tingkat Kontrol Diri Dengan Kecenderungan Perilaku Kenakalan Remaja. Jurnal Psikologi Pendidikan dan Perkembangan Fakultas Psikologi Universitas Airlangga Surabaya, Volume. 01 No. 02, 1-6.

Gulo, W. 2010. Metodologi Penelitian. Jakarta: Grasindo.

Gunarsa, S.D., 2010. Psikologi Praktis: Anak, Remaja, dan Keluarga. Jakarta: PT. BPK Gunung Mulia.

Ghufron, M. Nur \& Risnawati, Rini. 2010. Teori-teori Psikologi. Yogyakarta: ArRuzz Media.

Kartika \& Farida. (2008). Konseling Sebaya untuk Meningkatkan Efikasi Diri Remaja terhadap Perilaku Beresiko. Laporan Penelitian Fakultas Ilmu Pendidikan Universitas Negeri Yogyakarta

Kuncoro Komariah. (2015). Acara Program Talk Show with Kritaya (TAWA). Radio KPFM 96,8 fm Samarinda pada hari kamis, 10 Juni 2015 jam 06:15:00.

Pratiwi. 2004. Pendidikan Seks Untuk Remaja. Yogyakarta: Tugu Publisher.

Sarwono, S.W, 2012. Psikologi Remaja. Jakarta:

PT. Raja Grafindo Persada

Sarwono, Sarlito W. 2012. Pengantar Psikologi

Umum. Jakarta: Rajawali Press.

Sarwono, Sarlito W., Meinarno, Eko. A. 2009. Psikologi Sosial. Jakarta: Salemba Humanika.
Sugiyono. 2011. Metode Penelitian Kuantitatif Kualitatif dan $R \& D$. Bandung: Alfabeta.

Santrock, John W. 2002. Life Span Development (Perkembangan Masa Hidup) edisi kelima jilid 2. Jakarta: Erlangga.

Thalib, S.B. 2010. Psikologi Pendidikan Berbasis Analisis Empiris Aplikatif. Jakarta: Kencana Prenada Media Group.

Trida Cynthia. 2007. Konfirmitas Kelompok dan Perilaku Seks Bebas Pada Remaja. Jurnal Psikologi Fakultas Psikologi Universitas Gunadarma, Volume 1, No. 1, 75-80.

Yulinto. 2010. Gambaran Sikap Siswa SMP Terhadap Perilaku Seksual Pranikah (Penelitian Dilakukan Di SMPN 159 Jakarta). Jurnal Psikologi Fakultas Psikologi Universitas Esa Unggul Jakarta, Volume 8, Nomor 2, 48-57.

Walgito, B. 2002. Pengantar Psikologi Umum. Yogyakarta: Penerbit Andi. 